\title{
Institutional pressures and corporate environmental management maturity
}

\begin{abstract}
Purpose - This paper examines how corporate environmental management strategies at different environmental management maturity (EMM) stages are influenced by institutional forces in the service sector organizations of a developing country.

Design/methodology/approach - We used a multiple case study approach in this study. Institutional isomorphic pressures (coercive, mimetic and normative) at different EMM stages were used as the analytical framework.

Findings - The study finds coercive pressures largely shape the corporate environmental management strategies at the reactive stage while mimetic pressures have the greatest influence on the internal integration stage. Combined mimetic and normative pressures influence the environmental strategies at the external integration stage. Further, it emphasizes the importance of various institutional pressures in propelling the organizations in the developing countries to benefit from higher levels of EMM.
\end{abstract}

Originality/value - This paper offers a new theoretical approach that highlights the importance of considering the institutional influence of the top-down process of diffusion and simultaneous counter-process of invention by which the lower level organizational actors shape and change their environmental management practices for corporate EMM.

Paper type - Research paper

Key words - Corporate environmental management maturity, Developing countries, Institutional theory, Service sector, Sustainable management strategies.

\section{Introduction}

There is growing attention to current global environmental problems whose scope and scale have expanded considerably over the past decades (Jabbour, 2010; Mysterud, 2017; Welford, 2013). Since many researchers consider companies to be responsible for many of these environmental and social problems (Herold and Lee, 2017; Schaltegger and Wagner, 2011; Schaltegger et al., 2016; Sonenshein, 2016), there is growing regulatory and social pressure on businesses expanding their corporate responsibility to include environmental and social issues at all levels of operation (El-Kassar and Singh, 2018; González-Benito and González-Benito, 2006; Judge et al., 2010; Maialle and Jabbour, 2014; Lee et al., 2017; Ormazabal and Sarriegi, 2012; Schaltegger and Wagner, 2011; Sonenshein, 2016). These demands have taken environmental sustainability into the boardrooms of corporations worldwide (Calza et al., 2016; Dixon-Fowler et al., 2017; Landrum, 2017) while making corporate environmental management an important function of companies in contributing towards sustainable development (Buysse and Verbeke, 2003; Fujii and Managi, 2016). This has further been influenced by shareholder activists who are motivated not only by financial drives but also by social reasons (Judge et al., 2010). Alongside this practical importance, corporate environmental management has also been subject to extensive research over the decades covering a wide spectrum. An important strand of research 
that still interests academics and practitioners alike is the taxonomies of the development of corporate environmental management practices (Ferreira et al., 2017; Hunt and Auster, 1990; Jabbour et al., 2010, Jabbour and Santos, 2006; Kolk and Mauser, 2002; Ormazabal et al., 2017; Ormazabal and Sarriegi, 2012; Shrivastava and Hart, 1995). Most of these studies attempt to systematize and classify corporate environmental management practices into different phases of development based on the level of environmental management integration. These phases, referred to as maturity, development or evolutionary stages, reflect a higher level of environmental management integration over time encompassing a wide range of organizational activities while investing substantial organizational resources in them. Despite the global importance of corporate environmental management, most of the EMM studies so far have focused only on developed countries, except Brazil (see Ferreira et al., 2017; Jabbour et al., 2010; Jabbour, 2010). This is an important factor to consider since developing countries face greater difficulties than developed countries in dealing with environmental (and social) problems due to inadequate environmental legislation, weak governance systems, widespread poverty, institutional capacity for the purpose and social infrastructure (Christmann and Taylor, 2002; Gunarathne et al., in press; Herzig et al., 2012; Lee at al., 2016; Patnaik et al., 2017; United Nations, 2017). Further, developing countries are under immense pressure to deal with a variety of environmental problems while achieving economic growth (Hiroyuki, 2001). This is important in a context where the emerging economies or developing countries the world over have undertaken many market reform activities to facilitate the integration of domestic markets with global markets (Singh et al., 2018). The institutional context and the pressures exerted by these institutions for sustainability in these countries are different to those of developed countries but so far they remain largely unexplored (Lee and Schaltegger, 2018). Thus this study aims to address how the institutional pressures on companies in developing countries influence the adoption of environmental management practices at different stages of EMM taking Sri Lanka as the focus.

The importance of this study can also be grounded on its focus on the non-manufacturing sector, and service sector in particular (Merchant and Gaur, 2008). Owing to their visible impact, most research on corporate environmental management practices has focused on manufacturing industries (Foster et al., 2000; Gunarathne and Lee, 2015; Lucas and Wilson, 2008; Moreno et al., 2004). Therefore, environment-related questions in service sector firms have not yet been addressed adequately though they play a significant role in both developed and developing countries (Foster et al., 2000; Moreno et al., 2004; Salzman, 2000). On the other hand, understanding the environmental impact of the service sector is much more difficult as it covers a much more heterogeneous collection of economic activities (Moreno et al., 2004) than manufacturing firms. Similarly, understanding the sources of competitive advantage of service firms is still an important area for empirical research (Merchant and Gaur, 2008). For instance, how service firms can embed environmental sustainability in generating competitive advantage 
has not yet been subject to investigation. This paper aims to contribute to filling this lacuna in knowledge by focusing on the hotel sector in Sri Lanka.

Important contributions of the paper are as follows: First, the paper offers new theoretical insights into how various institutional pressures influence EMM. Although EMM and institutional influence on corporate environmental and sustainability management has been discussed widely, albeit in isolation, (Bansal, 2005; Campbell, 2007; Jabbour et al. 2010; Kolk and Mauser, 2002; Ormazabal and Sarriegi, 2014; Primc and Čater, 2016; Windolph et al., 2014a) how various institutional pressures shape the environmental management practices of the organizations at different intensity levels of environmental management (as identified by their maturity stage) has not yet received academic attention. Second, the study offers insights from South Asia contributing into the paucity of studies on corporate environmental management in developing countries. This is important as most of the corporate sustainability and environmental management studies have focused on developed countries ignoring the global importance of environmental and sustainability management (Gunarathne and Lee, 2015; Lee and Schaltegger, 2018). Hence, understanding how corporate contributions (or resistance) to sustainable development in some regions such as South Asia (known as SAARC) ${ }^{1}$, which currently has one of the highest economic growth rates in the world (World Bank, 2017) in their pursuit of economic development is important.

The rest of the paper is organized as follows. Section Two presents the literature review followed by the research methodology in Section Three. Section Four presents the findings and results of the study. Section Five provides the discussion, Section Six the implications and the last section the conclusions.

\section{Literature Review}

\section{Corporate environmental management maturity}

Corporate environmental management strategies, methods and tools constitute a positive contribution to environmental sustainable development (Cramer, 1998, Ormazabal and Sarriegi, 2014). Along with the developments in organizational practices, researchers have shown a keen interest in studying corporate environmental management practices. They reveal while some companies embrace ecologically responsible behaviours with advanced processes, there are companies in seemingly similar circumstances that are still experimenting or not even complying with existing regulations (Bansal and Roth, 2000; González-Benito and González-Benito, 2006; Ormazabal et al., 2017). Hence, they point to the importance of considering different levels of organizational adoption and development in environmental management (Buysse and Verbeke,

\footnotetext{
${ }^{1}$ The South Asian Association for Regional Corporation (SAARC) is an organization of eight countries including Afghanistan, Bangladesh, Bhutan, India, Nepal, the Maldives, Pakistan and Sri Lanka. SAARC region with its 1.7 billion people represent $21 \%$ of the world population but only occupies $3 \%$ of the world's land area (SAARC, 2015).
} 
2003; Clemens, 2001; Maialle and Jabbour, 2014; Murillo-Luna et al., 2011; Ormazabal and Sarriegi, 2014; Ormazabal et al., 2015; Park and Ahn, 2012, Primc and Čater, 2016).

Various classifications methods or taxonomies have been proposed to analyse corporate EMM. They can be broadly divided into a) progressive/developmental (maturity or evolutionary) models, and b) non-progressive/non-sequential (or typologies) models (González-Benito and González-Benito, 2006; Hass, 1996; Kolk and Mauser, 2002). The development models this study deals with, focus on how organizations integrate the environmental variable into their management activities while classifying companies according to their stage of environmental management evolution (Jabbour and Santos, 2006). These "maturity staging models deconstruct the operating processes of a firm, with each stage representing a more effective and efficient use of the firm's resources for achieving the firm's goals" (Ormazabal et al., 2017, p. 28). These diverse developmental models range from environmental reactivity in which companies only meet the regulatory requirement to environmental proactivity in which companies take voluntary measures to reduce the environmental impact (González-Benito and González-Benito, 2006). An exhaustive literature review based on the content analysis method (see Gaur and Kumar, 2018 for more details on conducting a literature reviews using content analysis) on EMM reveals that an increasing number of development models have been proposed over the last three decades (see Table 1).

Table 1: Different environmental management maturity stages

\begin{tabular}{ll}
\hline Author(s) & Development stages of environmental management \\
\hline Hunt and Auster (1990) & $\begin{array}{c}\text { Beginner, fire fighter, concerned citizen, pragmatist, } \\
\text { pro-activist } \\
\text { Non-compliance, compliance, compliance-plus, } \\
\text { leading edge, excellence }\end{array}$ \\
Roome (1992) & $\begin{array}{c}\text { Stable, reactive, anticipatory, proactive, } \\
\text { creative } \\
\text { Reactive, active, proactive } \\
\text { Azzone and Bertelè (1994) }\end{array}$ \\
Venselaar (1995) & $\begin{array}{c}\text { Prevention of prevention, environmental management } \\
\text { in products, sustainable development }\end{array}$ \\
Hart (1995) & $\begin{array}{l}\text { Band-aid, more serious, deep change } \\
\text { Non-compliance, compliance, beyond compliance } \\
\text { Shrivastava and Hart (1995) }\end{array}$ \\
Berry and Rondinelli (1998) & $\begin{array}{c}\text { Reactive strategy, prevention of pollution, } \\
\text { environmental leadership }\end{array}$ \\
Buysse and Verbeke (2003) & Control of pollution, prevention of pollution \\
Cagno et al. (2005) & $\begin{array}{l}\text { Regulatory, gross emissions, efficiency, life cycle } \\
\text { Rothenberg et al. (2005) }\end{array}$ Functional specialization, internal integration, external \\
Jabbour and Santos (2006) & integration
\end{tabular}


Murillo-Luna et al. (2011)

Garces-Ayerbe et al. (2016)

Ormazabal and Sarriegi (2012)

Ormazabal et al. $(2015,2017)$

Primc and Čater (2016)
Passive, attention to legislation, attention to stakeholder, total environmental quality

Laggards, initiated, proactive, eco-innovative

Legislation fulfilment, training, systematization, eco2, eco-innovative, leading green company

Reactors, defenders, analysers, prospectors

As the above table shows, there are diverse viewpoints on the number of stages and characterization of each stage. However, they all show that the evolution of environmental management tends to go through similar patterns in virtually all companies (Ormazabal and Sarriegi, 2012). After analysing the above taxonomies, it was decided to follow the taxonomy of Jabbour and Santos (2006) for two reasons. First, their taxonomy is based on a systematic analysis of similar taxonomies (Maialle and Jabbour, 2014) and second, the applicability of this taxonomy has been empirically tested in several studies (Ferreira et al., 2017; Jabbour et al., 2010; Jabbour, 2015; Teixeira et al., 2012). The following table shows some of the salient features of the Jabbour and Santos (2006) corporate EMM model (see Table 2).

Table 2: Salient features of environmental management in companies

\begin{tabular}{llll}
\hline & $\begin{array}{l}\text { Functional } \\
\text { specialization stage }\end{array}$ & $\begin{array}{l}\text { Internal integration } \\
\text { stage }\end{array}$ & $\begin{array}{l}\text { External integration } \\
\text { Stage }\end{array}$ \\
\hline Focus & $\begin{array}{l}\text { Complying with } \\
\text { regulations or } \\
\text { stakeholder } \\
\text { expectations }\end{array}$ & $\begin{array}{l}\text { Better utilization of } \\
\text { inputs and initiation of } \\
\text { projects in } \\
\text { environmental } \\
\text { management }\end{array}$ & $\begin{array}{l}\text { Exploring the } \\
\text { opportunities for } \\
\text { improving the } \\
\text { competitiveness in the } \\
\text { external context }\end{array}$ \\
$\begin{array}{lll}\text { Company } \\
\text { perception }\end{array}$ & $\begin{array}{l}\text { Additional cost of } \\
\text { compliance }\end{array}$ & $\begin{array}{l}\text { Tool for improving } \\
\text { eco-efficiency }\end{array}$ & $\begin{array}{l}\text { Means of achieving } \\
\text { competitive advantage }\end{array}$ \\
$\begin{array}{l}\text { Role and } \\
\text { support of top } \\
\text { management }\end{array}$ & Limited & Linked to the & Continuous \\
& & improvement of eco- & \\
efficiency &
\end{tabular}

Source: Adapted from Jabbour et al. (2010) p. 1054

\section{Institutional theory}

The adoption of sustainability management practices (or even corporate socially responsible behaviours) has been often explained through institutional theory (Bansal, 2005; Boiral, 2002; 
Campbell, 2007; Judge et al., 2010; Patnaik et al., 2017; Windolph et al., 2014a). In this study too we were motivated to use institutional theory as our theoretical model as it provides rich insights into the adoption of environmental management strategies/practices in the organization of a firm (Bansal, 2005; Campbell, 2007; Delmas and Toffel, 2004; Kang and Lee, 2016) such as the hotel industry which is the subject of this study. In order to systematize the different strands of institutional theory, Scapens (2006) suggests three categories, viz, new institutional economics (NIE), which identifies the structures used to govern economic transactions; new institutional sociology (NIS), which considers the institutions in the organizational environment that shape organizational structures and systems; and old institutional economics (OIE), which focuses on the institutions that shape the actions and thoughts of individual human agents. Since the focus of this study is on identifying how institutional pressures in the hotel field shape the environmentoriented organizational structures and systems at different EMM stages, we use NIS as the analytical framework of this study. According to NIS, structural changes in organizations can occur as a result of processes that homogenize organizations, which process is called isomorphism (DiMaggio and Powell, 1983). There are three mechanisms through which institutional isomorphic changes occur: 1) coercive isomorphism that stems from political influence and the problem of legitimacy; 2) mimetic isomorphism resulting from standard responses to uncertainty; and 3) normative isomorphism, associated with professionalization (DiMaggio and Powell, 1983).

Coercive isomorphism results from both formal and informal pressures exerted on organizations by other organizations upon which they are dependent (DiMaggio and Powell, 1983). Powerful stakeholders such as regulators, foreign investors, non-governmental organizations, standardization agencies, industry norms, parent companies, and rating organization can exert coercive pressure on organizations to follow sustainability practices (Bansal, 2005; Amran and Haniffa, 2011; Windolph et al., 2014a). Such pressures may be felt to be force, persuasion, or invitation to join in collusion (DiMaggio and Powell, 1983). By complying with expectations, standards, guidelines of standard organizations and sustainability rating agencies, companies attempt to receive social legitimacy through sustainability management (Windolph et al., 2014b).

Mimetic isomorphism can be induced by uncertainty and consequently organizations model themselves on other organizations as a convenient source of practices (DiMaggio and Powell, 1983). Sustainability management tools, approaches and principles that often overwhelmingly appear in academic research create uncertainty for practitioners (Windolph et al., 2014a). In such situations organisations may follow the practices followed by a significant number of organizations (Abrahamson, 1991). This mimicry of corporate sustainability can take place indirectly through employee transfer or turnover, or explicitly by sustainability organizations such as consulting firms or industry trade associations (DiMaggio and Powell, 1983, Windolph et al., 2014b). According to Grob and Benn (2014), these would include voluntary reporting 
frameworks such as the Global Reporting Initiative (GRI) and environmental management systems.

Normative isomorphism stems primarily from professionalization (DiMaggio and Powell, 1983), deriving from professional networks, corporate sustainability associations and education and training (Bansal, 2005; Campbell, 2007; DiMaggio and Powell, 1983; Windolph et al., 2014a). Hiring of individuals from the same industry, recruitment of staff from a narrow range of training institutions and common promotion practices and skill-level requirements for particular jobs can result in normative isomorphism (Grob and Benn, 2014).

By combining corporate EMM with NIS theory we use the following framework, which is synthesized as the core analytical framework of this study (See Figure 1). This figure is built on the notion that the organizational field is the unit of analysis in institutional theory. Figure 1 also embodies the top-down process of diffusion and the simultaneous counter-process of invention by which lower level organizational actors shape and change the contexts within which they operate (Scott, 2008). Figure 1 also highlights that due to the complex interaction between institutional pressures and organizational units at different EMM stages, there will be different forms of corporate environmental management practices.

\section{Figure 1: Analytical framework of the study}

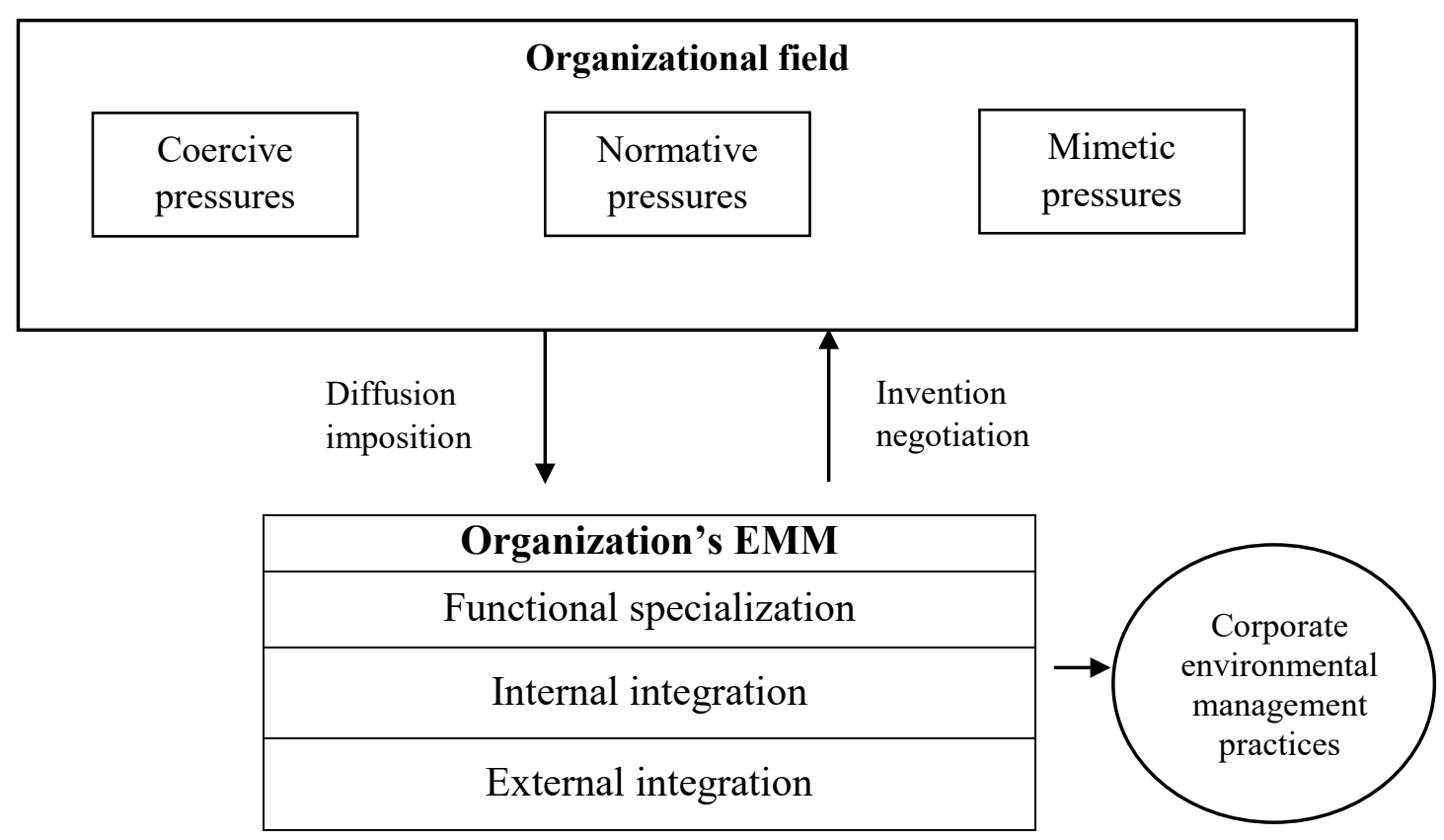




\section{Research Method}

In this study, we selected travel and tourism sector as our industry since it is an important economic sector in the global economy that creates jobs, drives exports, and generates wealth. The World Travel and Tourism Council (WTTC) (2017) reports that this sector contributed $10.2 \%$ of global Gross Domestic Product (GDP) and generated 1 in 10 of the world's total jobs. Environmental sustainability is crucial to this sector as the survival of tourism relies heavily on the quality of the natural and physical environment (Hashimoto, 1999). Further, the importance of the tourism sector for global sustainable development was highlighted when the United Nations designated 2017 as the International Year of Sustainable Tourism for Development (WTTC, 2017). While tourism plays a crucial role in achieving many of the Sustainable Development Goals (SDGs) such as achieving inclusive and sustainable economic growth, reducing poverty, improving resource efficiency and reducing climate change and promoting peace and diversity, the industry faces the growing challenge to sustainably manage an expected 1.8 billion international tourists in 2030 (United Nations World Tourism Organization, UNWTO, 2017).

The data for this study was collected as part of an ongoing research project that explored corporate environmental management practices in Sri Lanka based on a case study approach as the research question was concerned with a contemporary real life phenomenon of organizational and managerial issues (Myers, 2003; Yin, 2009). We selected three hotel groups for analysis, hereafter referred to as Hotel Group 1, Hotel Group 2 and Hotel Group 3. These three hotels are in different corporate EMM stages and were categorised according to the EMM stage based on the situation that best describes them. Three situations were described for each of the three EMM stage and the descriptions contained several characteristics that enabled determining the EMM stage (see Table 3).

Table 3: Characteristics for categorization based on corporate EMM

\begin{tabular}{lll}
\hline Organization & Characteristics of corporate environmental & EMM stage \\
& management practices [Note1] & \\
\hline Hotel 1 & Strong emphasis on end of pipe technologies & Functional \\
& Inclusion of environmental considerations to the specialization \\
& business operations is reactive to environmental \\
& legislation. \\
& Environmental expertise of the company is not \\
& articulated. \\
& Environmental performance appraisal of the supplier is \\
& not carried out or is not systematic. \\
& Environmental management focuses on increasing the Internal integration \\
& efficiency of natural resources such as water, energy \\
Hotel 2 & and raw materials.
\end{tabular}


Environmental management is linked to the prevention of pollution.

Environmental performance appraisal of the supplier is becoming systematic.

Hotel 3 Environmental management focuses on creating External integration opportunities.

Innovations focus on exploring new market niches.

Process innovations focus on improving the productivity of natural resources in a systematic way.

Continuous improvement of annual goals of reduction in pollution and its sources.

Environmental performance appraisal of the supplier is systematic.

Note 1: These characteristics were developed based on Jabbour et al. (2010)

Hotel Group 1 is a well-known hospitality group in Sri Lanka and we selected three hotels in Negombo. Hotel Group 2 belongs to one of the largest diversified conglomerates in Sri Lanka and we selected two hotels in Colombo. Hotel Group 3 also belongs to a diversified conglomerate in Sri Lanka and we selected two hotels, one in Sigiriya and the other in Negombo. Thus, we selected seven hotels in different geographical locations of the country. All these hotel groups are listed on the country's Stock Exchange and the clientele comprises a mixture of local and international up-end tourists.

We visited all the hotels in Hotel Group 1 and 2 and the hotel in Sigiriya in Hotel Group 3. During our visits we mainly interviewed the General Manager, the hotel's Naturalist or Environmentalist and the Chief Engineer of each hotel during Jan 2017 to May 2017. In Hotel Group 2 we interviewed the Health and Safety Manager who handles waste management. The interviews with the General Managers were relatively short and lasted about twenty minutes on average. We had in-depth interviews with Chief Engineers and the Naturalist/Environmentalist. The duration of these interviews ranged from forty minutes to two hours. Most of them were electronically recorded with their consent for later analysis. During our on-site observations, we observed the physical evidence pertaining to the operation of environmental management practices such as boilers, chillers, sewerage treatment plant, kitchen, laundry, hotel rooms, lobby, etc. Depending on the practical feasibility, we further interviewed a few guests and various other hotel staff (Accountant in Hotel Group 3, Quality Assurance Manager, Department Managers, Chief Steward, and members of the hotel's Green Committee) as a means of cross-checking and confirming the practices so as to increase the research validity of our findings. We also referred various internal records of the hotels for collecting secondary data. These internal records included monthly and weekly energy records, project proposals, Green Directory, waste collection sheets, waste disposal records, etc. Finally, we also interviewed an officer of the 
Central Environmental Authority (CEA) representing regulators. These interviews were semistructured with open-ended questions. We also referred other online data such as web sites of the hotels, Acts, annual reports, etc. As a mean of triangulation, we used non-participative observations, physical inspections of artefacts and content analysis of the documents (Chan, 2009; Golafshani, 2003; Yin, 2009). The collected data was analysed based on the analytical framework developed in the study.

\section{Findings and analysis}

\subsection{Coercive pressures on environmental management practices}

There are certain legislations that influence the environmental management practices of the hotel sector of Sri Lanka. Among them the Environmental Protection Licence (EPL) that every hotel has to obtain from the CEA on an annual basis is important (Government Information Centre, 2014; Gunaruwan and Josep, 1999). When this licence is issued CEA evaluates how waste, especially waste water and effluents, are disposed of. The gazette notification with regard to the issue of EPL for emission or disposal of waste is as follows:

"No person shall discharge, deposit or emit waste into the environment or carry on any prescribed activity ... in circumstances which cause or are likely to cause pollution, or noise pollution”. (The Gazette of the Democratic Socialist Republic of Sri Lanka- Extraordinary, 2010)

Apart from this minimum regulatory requirement, it is difficult to identify other direct standard operating procedures or structures of influential institutions that exert coercive pressure on the hotel sector in Sri Lanka. There was a hotel greening programme called "greening the hotels" operated by SwitchAsia in collaboration with the Ceylon Chamber of Commerce (SwitchAsia, 2010). However, it is not in operation now. The Chief Engineer of Hotel Group 2 expressed his dismay over the cessation of this programme:

"SwichAsia programme is the only structured environmental management programme we had so far. Unfortunately it is not in operation now... We have no clear guidance from the government or any other institution."

In our study, as seen in Hotel Group 1, the environmental management practices of the organizations in the functional specialization are primarily driven by the need to comply with legislative requirements. The Chief Engineer of the Hotel 1 confirmed this:

"Our main purpose is to comply with the EPL [i.e. legislative aspects] requirements. We take all the steps to meet these requirements... When the regulations change we are keen to incorporate them into our operations since non-compliance can create various problems."

His statement further confirms that the organizations in the functional specialization stage adopt a reactive approach to corporate environmental management (Roome, 1992; Jabbour and Santos, 
2006; Buysse and Verbeke, 2003). Hence, these organizations perceive meeting legislative requirements sufficient for carrying out their business activities. Since much of the legislation focuses on reducing the immediate damage to the environment, these organizations place greater emphasis on end-of-pipe technologies (Roome, 1992) such as managing waste water or solid waste. Hence, their environmental management strategies are too fragmented and limited in scope to cover immediate environmental problems such as waste water and solid waste (Gunarathne and Lee, 2015).

Since these organizations still consider environmental compliance an additional cost, the environmental expertise of the company is not articulated, primarily due to the lack of resource allocation (Jabbour and Santos, 2006). The General Manager of Hotel Group 1 confirmed this:

"We still do not see the need to have a separate division for environmental management. Perhaps in the future depending on how the legislations and other factors change, we will consider having more resources for environmental sustainability."

Further, due to this limited scope and resources for environmental management and noncoverage of these aspects by legislation, organisations in the functional specialization stage do not carry out an environmental performance appraisal of the supplier (Jabbour and Santos, 2006; Jabbour et al., 2010).

However, the organizations in the internal and external specialization stages go beyond these regulatory requirements. As shown in our study, Hotel Groups 2 and 3 hold similar views on the impact of coercive pressures on environmental management. As EPL is only general in nature, i.e., applicable to all the industries in Sri Lanka, the influence it bears on a hotel's environmental practices at these stages seems to be minimal. Therefore Hotel Groups 2 and 3 dispose of their waste in a more responsible manner than required by EPL. The Chief Engineer of Hotel Group 3 said:

"The environmental regulations applicable to our sector are very minimum and basic. We actually go beyond the regulations to manage waste, mostly on a voluntary basis."

Reaffirming this, the Health and Safety Manager of the Hotel Group 2 said:

"In fact, EPL stipulates that waste has to be properly disposed of. In that case even giving waste to a municipal council is enough. But we try to manage waste in-house as much as possible and only what we can't manage is given to the municipal council." 
These statements indicate that the impact of coercive pressure on the organizations at higher levels of EMM has no bearing on the regulatory requirements. Their focus is to always exceed the minimum requirements set out in the legislation owing to other institutional pressures.

\subsection{Normative pressures on environmental management practices}

Normative isomorphic pressures arising from the professionalization of the members of an occupation defining their working conditions and practices (DiMaggio and Powell, 1983) can be witnessed through sources such as professional networks, sustainability associations and education and training requirements (Bansal, 2005; Campbell, 2007; Windolph et al., 2014a). In general, many of the environmental management practices of the hotel sector in Sri Lanka affected by normative pressures are due to the hiring of professional with the same background or universities.

Organizations in the functional specialization stage, as in Hotel Group 1, do not have a specialized department/expertise for corporate environmental management. They are usually carried out by the Engineers who oversee the other day-to-day operations of the hotel (Gunarathne et al., 2015). Hence the influence of the normative pressures on corporate environmental management strategies in terms of professionalization is minimal in organizations at the functional specialization stage.

Organizations at the internal integration and external integration stage focus on increasing the efficiency of natural resources such as water, energy and raw materials (Jabbour and Santos, 2006). These organizations hence employ skilled personnel such as Naturalists/Environmentalists or dedicated (Environmental) Engineers to carry out these activities. These Engineers belong to engineering faculties of the country or technical colleges. The Naturalists/Environmentalists usually possess a degree in environmental management. It is thus evident that the hiring of professionals of similar educational background has largely shaped the environmental management practices of the hotel sector. The Chief Engineer of Hotel Group 2 said the following in respect of their recruitment policy:

"We always hire engineers for environmental management who have a basic degree in engineering with some specialization in environmental related fields. Also they need to have at least five years of experience in the industry including a minimum two years' experience in the hotel sector."

In addition to a similar education background, similar training or experience has also affected the environmental strategy of the hotels at the internal integration and external integration stages. We observed that these Engineers and/or Naturalists/Environmentalists prefer to work in the hotel sector even when they change their organization. This too acts as normative pressure which shapes the environmental practices of the hotels. The Chief Engineer of Hotel Group 3 stated: 
"We know each other [the Engineers of the other hotels] well. We sometimes visit their hotels or they come and visit us. For example, one of my subordinates joined Hotel xx (name is not disclosed) and he has started to use kitchen oil in their boiler which we do here normally."

The above statement highlights the influence of similar training or industry experience in influencing the environmental strategy of the hotel sector organizations at the internal and external integration stages.

Furthermore, in Hotel Group 3 we observed some advanced environmental management practices that go beyond common environmental aspects such as water, waste and energy. The hotel has implemented certain biodiversity and carbon management practices initiated by the Naturalists. A General Manager of Hotel Group 3 said:

"In the last couple of years we have introduced many carbon and biodiversity management and reporting practices systematically, thanks to the Naturalist we recruited for environmental management of the hotel. He has a degree in biodiversity and natural resource management and it is this background that has provided him a sound foundation to initiate these practices which you do not find in many other hotels in the country. In fact, he was instrumental in setting up many proper systems and procedures in place [for environmental management]."

This statement of the General Manager shows the effect of normative pressure (i.e., education background of specialists employed for environmental management) in the organizations at the external integration stage in shaping advanced and structured management approaches in environmental domains that are less common such as biodiversity management.

\subsection{Mimetic pressures on environmental management practices}

Consulting firms, industry trade associations, voluntary reporting frameworks and environmental management systems can induce mimetic isomorphism (DiMaggio and Powell, 1983; Grob and Benn, 2014; Windolph et al., 2014a). Among these various mimetic pressures, the impact of ISO certification is important in the hotel sector of Sri Lanka. In particular, management of energy, water and food is largely affected by accreditation for ISO 14000, 22000 and 50001 standards (Gunarathne et al., 2015).

Hotel Group 1 has obtained neither any environmental management certifications nor engaged in any sustainability-related disclosures in their annual reports. Hence, the influence of mimetic pressures on organizations at the functional specialization stage is very minimal, as revealed in Hotel Group 1. As stated previously, their focus on environmental management does not go beyond the requirements specified in legislation. 
According to Hotel Groups 2 and 3, the influence of mimetic pressures is quite visible in organizations at internal integration and external integration stages. Both Hotel Groups 2 and 3 have obtained ISO 14000 and ISO 50001 certification. The Chief Engineer of Hotel Group 2 mentioned about their motivation to go for ISO 50001 as follows:

"ISO 50001 certification is now becoming common in our industry. In addition, it streamlines your energy management system... ISO accreditation brought a lot of changes in the way we managed and especially the way we reported on energy management."

From his statement it is clear that ISO accreditation shaped their energy management practices to a great extent. As the focus of the organizations on the internal integration stage is to improve the efficiency of resource consumption (Jabbour and Santos, 2006), mimetic pressures such as environmental accreditation support their objective.

In addition, both Hotel Groups get the help of consulting firms in managing energy and calculating the carbon footprint especially because proper guidance is not forthcoming from industry trade associations or government. Since there are very few specialized environmental consulting firms in the country, the environmental practices adopted by the hotels largely resemble each other. Energy saving practices such as use of LED and alternative bio fuel, thermal insulation, deployment of intelligent thermostats, maximization of natural ventilation and waste management practices such as the use of sewerage treatment plants, separation at the point of generation, non-use of toxic chemicals and minimization of plastic and polythene are commonly adopted in both Hotel Groups 2 and 3 encouraged by external consultants. Also, the Green Directory $^{2}$ as an internal sustainability measurement and reporting mechanism is adopted by Hotel Groups 2 and 3. The General Manager of Hotel Group 2 said:

"We started following most of these environmental practices after we got the service of consultants. Even before that we had some reporting structure. But the concept of Green Directory provided a good structure for us to identify, measure, and report what we do... Also to provide the information for the Green Directory we also have to follow/change many practices."

The Chief Engineer of Hotel Group 3 also agreed:

"The Green Directory is a concept introduced by the environmental consultant we hired. This has now become a common practice among many hotels in the country."

\footnotetext{
${ }^{2}$ Green Directory is a book prepared by the hotels showcasing their various environmental management actions. The information for the Green Directory such as energy, water, waste, food, etc is supplied by all the departments in a hotel to the engineering division.
} 
This suggests that the Green Directory, a mechanism introduced by mimetic isomorphic pressure, has become a means of collecting and reporting environmental sustainability information. Further it reflects the influence of mimetic pressures in shaping the environmental management practices of organizations in the internal and external integration stages.

Although the influence of mimetic pressures is visible in organizations in both internal and external integration stages, it is more visible in organizations in the external integration stages, as revealed by Hotel Group 3. In this regard the influence of the GRI reporting system is clearly evident in the environmental management practices of Hotel Group 3, (Grob and Benn, 2014). Though all the hotels in this study are listed in the country's Stock Exchange, it is only Hotel Group 3 that prepares a sustainability report based on GRI guidelines. The Accountant of Hotel Group 3 stated:

"We usually benchmark the sustainability leaders in and outside our industry and their reporting practices... And we also continuously endeavour to improve our sustainability reporting based on GRI Guidelines... To comply with GRI guidelines we have to push the hotels to follow a lot of practices here."

Confirming this view, the General Manager of Hotel Group 3 stated:

"I think the biggest factor that streamlined our practices was the adoption of GRI guidelines for reporting sustainability. It enabled us to have a very structured approach [for corporate environmental management] for many of the environmental factors such as energy, water, carbon, etc... It also provided us evidence of how far we have improved compared to previous years."

This is in line with the argument put forward by Schaltegger et al. (2006) of accounting-driven sustainability. Further, it indicates how sustainability reporting has created mimetic pressure on the environmental management practices (Grob and Benn, 2014; Windolph et al., 2014a) of organizations in the external integration stage.

The General Manager of Hotel Group 3 further stated:

"We use these aspects [i.e., unique environmental management practices] in our web sites and other promotional materials especially to attract international greenconscious guests, who we believe are a growing customer segment. Our organization has deployed a considerable amount of resources on sustainability and we always try to capitalize on what we do".

This statement provides evidence of how the organizations in the external integration phase aim to generate competitive advantage and explore emerging opportunities in the market through 
corporate environmental management strategies (Gunarathne and Lee, 2015; Jabbour and Santos, 2006; Roome, 1992) fostered by various mimetic and normative pressures.

The next section provides the discussion based on these findings.

\section{Discussion}

As revealed in our study, the effect of institutional pressures on organizations at different corporate EMM stages can be summarized as in see Table 4.

Table 4: Effect of institutional pressures at different corporate EMM stages

\begin{tabular}{|c|c|c|c|}
\hline \multirow{2}{*}{$\begin{array}{l}\text { Stage of } \\
\text { corporate EMM }\end{array}$} & \multicolumn{3}{|c|}{ Institutional pressure for environmental management } \\
\hline & Coercive & Normative & Mimetic \\
\hline $\begin{array}{l}\text { Functional } \\
\text { specialization }\end{array}$ & $\begin{array}{l}\text { Primarily driven by } \\
\text { these pressures }\end{array}$ & $\begin{array}{l}\text { Minimum } \\
\text { consideration }\end{array}$ & $\begin{array}{l}\text { Minimum } \\
\text { consideration }\end{array}$ \\
\hline Internal integration & $\begin{array}{l}\text { Goes beyond these } \\
\text { compulsory } \\
\text { requirements }\end{array}$ & Medium consideration & $\begin{array}{l}\text { High level of attention } \\
\text { given }\end{array}$ \\
\hline $\begin{array}{l}\text { External } \\
\text { integration }\end{array}$ & $\begin{array}{l}\text { Goes well beyond these } \\
\text { compulsory } \\
\text { requirements }\end{array}$ & $\begin{array}{l}\text { High level of attention } \\
\text { given }\end{array}$ & $\begin{array}{l}\text { Very high level of } \\
\text { attention given }\end{array}$ \\
\hline
\end{tabular}

Environmental management practices of the organizations in the functional specialization stage have been largely shaped and influenced by coercive pressure in the organizational field. Hence, the environmental strategy of the functional specialization stage organizations is reactive and is set by legislation focusing on a few environmental domains such as water and waste (Berry and Rondinelli, 1998; Buysse and Verbeke, 2003; Jabbour and Santos, 2006; Ormazabal and Sarriegi, 2014; Roome, 1992). Our study also demonstrates that while combined mimetic and normative pressure has the highest influence on organizations in the external integration stages, as suggested by Bansal (2005). On the other hand, our study manifests that normative pressures too exert influence on organizations in the internal integration stages.

In general, our study highlights the lack of industry specific regulations and governance systems as a major impediment to the progress of organizations to reach higher levels of EMM (or more broadly corporate socially responsible behaviour) in developing countries, as suggested by Christmann and Taylor, (2002), Herzig et al, (2012) and Patnaik et al. (2017). Most of the available legislation is general and not industry-specific. Therefore the industries can easily meet the regulatory requirements. Further, the governments of these countries have either neglected the environment in their development pursuits or have been reluctant to enact more stringent industry-specific environmental laws governing industries for fear of discouraging investments (Christmann and Taylor, 2002). They argue that 'lax' environmental regulations and law 
enforcement are followed by developing countries to attract foreign direct investment. Hence, as seen in Hotel Group 1, most organizations may remain in the functional specialization stage without necessarily progressing toward advanced levels of EMM. Without top management support and resources, environmental management will simply be a reactive approach (DixonFowler et al., 2017; Jabbour and Santos, 2006; Jabbour et al., 2010). In the absence of other powerful institutions such as rating agencies or industry guidelines, the role of government in developing countries is important in propelling the companies to higher levels of EMM.

As our study also reveals, many industries including the travel and tourism sector in developing countries suffer from a lack of guidance from the government or industry- specific trade associations in the adoption of systematic environmental management practices. Due to this inadequate coercive pressure many organizations have started to follow environmental management practices on a voluntary basis. However, the intensity of these voluntary actions depends on many contextual factors such as top management commitment, pressure from stakeholders and financial and technical knowhow of organizations (Chung and Parker, 2008; Gunarathne and Lee, 2015; Moreno et al., 2004). This situation has inevitably resulted in various degrees of intensity in their approach to environmental management even in the same industry.

The study also reveals the important role played by environmental professionals (Bansal, 2005; Windolph et al., 2014a) such as Environmental Engineers, Health and Safety Officers or Naturalists/Environmentalists in implementing these environmental strategies particularly in organizations at the internal and external integration levels. However, except for the external integration stage organizations, there is an absence of or inadequacies in a structured and systematic organization-wide approach to implementing and communicating the environmental practices in organizations at other EMM stages. Influenced by normative and mimetic pressures, the deployment of specialists, resources and top management commitment (Jabbour and Santos, 2006) have helped the external integration stage organizations to explore market opportunities.

Finally, the study reveals that due to the internal and external pressures for green practices, the adoption and implementation of environment-friendly business activities is becoming crucial for the firms (El-Kassar and Singh, 2018) irrespective of their level of EMM. However, only a few firms will develop their systems and structures in response to the various institutional pressures for sustainability (Bansal, 2005; Boiral, 2002; Campbell, 2007; Windolph et al., 2014a). The adoption of green innovative practices that reduce the consumption of energy and generation of waste and emissions, and enhance the sustainable utilization of resources (El-Kassar and Singh, 2018) will provide a competitive edge for the firms that are at higher levels of EMM.

\section{Managerial and theoretical implications}

The findings of this study have several practical/managerial and theoretical implications. 
We believe they can be of relevance to industry, policy makers and regulators in both developing and developed economies. The findings point to the need for the gradual development of environmental-related institutional, governance and enforcement capacity in developing countries (Christmann and Taylor, 2002; El-Kassar and Singh, 2018; Patnaik et al., 2017). Compared to developed countries, developing countries suffer from a lack of these institutional, governance and enforcement mechanisms which, in turn, act as a barrier to the achievement of SDGs. Hence, the introduction of such mechanisms should be gradual in propelling the industries smoothly towards higher levels of environmental management. Further, in developing these regulations and enforcement mechanisms there should be a process of stakeholder engagement that would not deter economic development and social acceptance. This is essential as any restrictive legislations or any other governance mechanism can hinder the rapid economic growth of these countries and limit improvements in living standards. As Campbell (2007) puts it, "corporations will be more likely to act in socially responsible ways if there are strong and well enforced state regulations in place [and if] ... these regulations and enforcement capacities were developed based on negotiation and consensus building among corporations, government, and the other relevant stakeholders" (p. 955). As there are shareholder activists who are not only financially driven but also socially driven, this process of stakeholder engagement can be beneficial in economic and social (end environmental) terms (Judge et al., 2010). Hence, regulators or policy makers in developing countries should develop legislation and relevant institutional capacity through a gradual consensual process having considered potential longterm economic and social implications. On the other hand, our findings further highlight the need for holistic multi- or trans-disciplinary sustainability education to foster higher order organizational performances and outcomes through corporate environmental management strategies (Schaltegger et al., 2013; Tingey-Holyoak and Burritt, 2012). As our study reveals, due to the impactful influence of normative pressure in shaping the environmental management practices in organizations at internal and external levels, there is a need for a holistic transdisciplinary (or multidisciplinary) approach to sustainability education in which the universities and professional education bodies can play an active role (Evans, 2015; RemingtonDoucette et al., 2013). This would pave the way for organizations to develop structured environmental management strategies to benefit from the advances in their EMM.

The theoretical implications of the study are manifold. First, it provides a new theoretical framing to analyse the different levels of EMM with the three isomorphic pressures suggested in the NIS branch of institutional theory. Although the various taxonomical explanations have been provided for corporate EMM (see Kolk and Mauser, 2002 for more details), no study has so far focused on how different isomorphic pressures can shape the environmental systems and structures of firms in an organizational field. Second, this study provides insights into corporate environmental management and institutional pressures for sustainability from the emerging economy (or developing country) context. Several scholars in the business domain have argued the need to shift the focus from developed markets to emerging markets (Singh et al., 2018). 
Also, given the fact that most of the EMM literature has so far focused on developed countries, this study fills this gap in the literature by providing an empirical case from Sri Lanka. This is a significant contribution as developing countries have different and weaker legislations, governance systems, institutional capacity and social infrastructure (Christmann and Taylor, 2002; Herzig et al., 2012; Lee at al., 2016; Patnaiket al., 2017). Third, this study identifies the EMM in the non-manufacturing sector in general and hotel sector in particular. As an important sub-sector of the tourism industry, the focus of this study has been on the hotel sector, which plays a pertinent role in contributing to many of the SDGs. With this focus, our study expands the understanding of corporate environmental management beyond the commonly studied manufacturing industries (Foster et al., 2000; Gunarathne and Lee, 2015; Lucas and Wilson, 2008; Moreno et al., 2004). Overall, our study is expected to promote future research on corporate environmental management and its maturity in the service sector industries in the developing countries.

\section{Conclusions}

The study identified the influence of institutional pressures on the corporate environmental management practices of service sector organizations at different EMM levels taking the Sri Lankan hotel sector. Our study highlights the need to consider the institutional influences in the discussion of corporate EMM so as to generate a better understanding of the top-down process of diffusion and the simultaneous counter-process of invention by which the lower level organizational actors shape and change their environmental management practices. It is also suggested that developing countries lack necessary regulatory and other coercive institutional capacity or mechanisms to foster higher order EMM. Thus, the development of environmental management strategies has been largely left in the hands of normative and mimetic institutions.

Our study however, is not without limitations. First, it is limited to a few organisations for indepth analysis so our findings lend themselves only to cautious generalization. They can only be theoretically generalized in a contextual way (Enquist et al., 2006). The three hotel groups we selected in the study are large and publicly listed. Due to their public visibility and financial feasibility, they may adopt many environmental management (or socially driven) practices when operating in a specific institutional environment (Judge et al., 2010). However, it may not be representative of the hotel sector nor other industries in developing countries. In future studies, it will be insightful to consider hotels of different sizes and customer profiles. Also in this study we did not consider the influence of the business groups on the institutional context of the industry as suggested by Lee et al (2017). It will also be necessary to consider other industry sectors in different developing countries too in order to obtain a better picture of the adoption of environmental management strategies in the developing country context.

\section{References}

Abrahamson, E. (1991), "Managerial Fads and Fashions: The Diffusion and Rejection of Innovations", The Academy of Management Review, Vol. 16 No. 3, pp. 586-612. 
Amran, A. and Haniffa, R. (2011), "Evidence in development of sustainability reporting: a case of a developing country", Business Strategy and the Environment, Vol. 20 No. 3, pp. 141156.

Azzone, G. and Bertelè, U. (1994), "Exploiting green strategies for competitive advantage", Long Range Planning, Vol. 27 No. 6, pp. 69-81.

Bansal, P. (2005), "Evolving sustainably: a longitudinal study of corporate sustainable development", Strategic Management Journal, Vol. 26 No. 3, pp. 197-218.

Bansal, P. and Roth, K. (2000), "Why Companies Go Green: A model of ecological responsiveness", The Academy of Management Journal, Vol. 43 No. 4, pp. 717-736.

Berry, M. A. and Rondinelli, D. A. (1998), "Proactive corporate environmental management: A new industrial revolution", Academy of Management Executive, Vol. 12 No. 2, pp. 38-50.

Boiral, O. (2002), "Tacit knowledge and environmental management", Long Range Planning, Vol. 35 No. 3, pp. 291-317.

Buysse, K. and Verbeke, A. (2003), "Proactive environmental strategies: A stakeholder management perspective", Strategic Management Journal, Vol. 24 No. 5, pp. 453-470.

Cagno, E., Trucco, P. and Tardini, L. (2005), "Cleaner production and profitability: analysis of 134 industrial pollution prevention (P2) project reports", Journal of Cleaner Production, Vol. 13 No. 6, pp. 593-605.

Calza, F., profumo, G. and Tutore, I. (2016), "Corporate ownership and environmental proactivity”, Business Strategy and the Environment, Vol. 25 No. 6, pp. 369-389.

Campbell, J. L. (2007), "Why would corporations behave in socially responsible ways? An institutional theory of corporate social responsibility", The Academy of Management Review, Vol. 32 No. 3, pp. 946-967.

Chan, W. W. (2009), “Environmental measures for hotels' environmental management systems ISO 14001”, International Journal of Contemporary Hospitality Management, Vol. 21 No. 5, pp. 542-560.

Christmann, P. and Taylor, G. (2002), "Globalization and the environment: Strategies for international voluntary environmental initiatives", Academy of Management Executive, Vol. 16 No. 3, pp. 121-135.

Chung, L. H. and Parker L. D. (2008), "Integrating Hotel Environmental Strategies with Management Control: a structuration Approach", Business Strategy and the Environment, Vol. 17 No. 4, pp. 272-286.

Clemens, B. (2001), "Changing environmental strategies over time: An empirical study of the steel industry in the United States”, Journal of Environmental Management, Vol. 62 No. 2, pp. 221-231.

Cramer, J. M. (1998), "Environmental management: From 'fit' to 'stretch"', Business Strategy and the Environment, Vol. 7 No. 3, pp. 162-172.

Delmas, M. and Toffel, M. W. (2004), "Stakeholders and Environmental Management Practices: An Institutional Framework", Business Strategy and the Environment, Vol. 13 No. 4, pp. 209-222. 
DiMaggio, P. J. and Powell, W. W. (1983), “The Iron Cage Revisited: Institutional Isomorphism and Collective Rationality in Organizational Fields”. American Sociological Review, Vol. 20 No. 1, pp. 122-36.

Dixon-Fowler, H.R., Ellstrand, A.E. and Johnson, J.L. (2017), "The role of board environmental committees in corporate environmental performance", Journal of Business Ethics, Vol.140, No.3, pp.423-438.

El-Kassar, A.-N. and Singh, S. K. (2018), "Green innovation and organizational performance: The influence of big data and the moderating role of management commitment and HR practices", Technological Forecasting and Social Change, doi:https://doi.org/10.1016/j.techfore.2017.12.016.

Enquist, B., Johnson, M. and Skalen, P. (2006), "Adoption of corporate social responsibility incorporating a stakeholder perspective", Qualitative Research in Accounting \& Management, Vol. 3 No. 3, pp. 188-207.

Evans, T.L. (2015), “Transdisciplinary collaborations for sustainability education: Institutional and intragroup challenges and opportunities", Policy Futures in Education, Vol. 13 No. 1, pp. 70-96.

Ferreira, M.A., Jabbour, C.J.C. and Jabbour, D.S.B.L. (2017), "Maturity levels of material cycles and waste management in a context of green supply chain management: an innovative framework and its application to Brazilian cases", The Journal of Material Cycles and Waste Management, Vol. 19 No. 1, pp. 516-525.

Foster, S. T., Sampson S. E. and Dunn S. C. (2000), "The impact of customer contact on environmental initiatives for service firms", International Journal of Operations \& Production Management, Vol. 20 No. 2, pp. 187-203.

Fujii, H. and Managi, S. (2016), "Trends in corporate environmental management studies and databases", Environmental Economics and Policy Studies, Vol. 18 No. 2, pp. 265-272.

Garces-Ayerbe, C., Scarpellini, S., Valero-Gil, J. and Rivera-Torres, P. (2016), "Proactive environmental strategy development: from laggard to eco-innovative firms", Journal of Organizational Change Management, Vol. 29 No. 7, pp. 1118-1134.

Gaur, A. S. and Kumar, M. (2018), "A systematic approach to conducting review studies: An assessment of content analysis in 25 years of IB research", Journal of World Business, Vol. 53 No. 2, pp. 280-289.

Golafshani, N. (2003), "Understanding Reliability and Validity in Qualitative Research", The Qualitative Report, Vol. 8 No. 4, pp. 597-607.

Gonzalez-benito, J. and Gonzalez-benito, O. (2006), "A review of determinant factors of environmental proactivity", Business Strategy and the Environment, Vol. 15 No. 2, pp. 87102.

Government Information Centre. (2014), "How to Implement Environmental Protection Licensing Procedure", available at: http://www.gic.gov.lk/gic/index.php?option=com info\&id=622\&task=info\&lang=en (accessed 14 December, 2017). 
Grob, S. and Benn, S. (2014), "Conceptualising the adoption of sustainable procurement: an institutional theory perspective", Australasian Journal of Environmental Management, Vol. 21 No. 1, pp. 11-21.

Gunarathne, N., Tennakoon, T. P. Y. C. and Weragoda, J. R. (in press), Challenges and opportunities for the recycling industry in developing countries: The case of Sri Lanka, Journal of Material Cycles and Waste Management. https://doi.org/10.1007/s10163-0180782-x

Gunarathne, N. and Lee, K.H. (2015), "Environmental Management Accounting (EMA) for Environmental Management and Organizational Change: An Eco-Control Approach", Journal of Accounting \& Organizational Change, Vol. 11 No. 3, pp. 362-383.

Gunarathne, N, Peiris, S, Edirisooriya, K. and Jayasinghe, R. (2015), Environmental Management Accounting in Sri Lankan Enterprises, Department of Accounting, University of Sri Jayewardenepura,

Sri Lanka.

Gunaruwan, T. L. and Josep, P. G., (1999), "Environmental Regulations and Technological Change in Industrial Activities in Sri Lanka", Sri Lanka Journal of Management, Vol. 4, No. 1 \& 2, pp. 597-607.

Hart, S. L. (1995), “A natural-resource-based view of the firm”, Academy of Management Review, Vol. 20 No. 4, pp. 986-1014.

Hashimoto, A. (1999), “Comparative evolutionary trends in environmental policy: Reflections on tourism development", International Journal of Tourism Research, Vol. 1 No. 3, pp. 195-216.

Hass, J. L. (1996), “Environmental ('green') management typologies: an evaluation, operationalization and empirical development", Business Strategy and the Environment, Vol. 5 No. 2, pp. 59-68.

Herold, D.M. and Lee, K-H. (2017), "Carbon management in the logistics and transportation sector: An overview and new research directions", Carbon Management, Vol. 8, No.1, pp. 79-97.

Herzig, C., Viere, T., Schaltegger, S. and Burritt, R. L. (2012), Environmental Management Accounting: Case Studies of South-East Asian Companies, Routledge, London.

Hiroyuki, T. (2001), 'Do developing countries enjoy latecomers' advantages in environmental management and technology? Analysis of the environmental Kuznets curve", International Review for Environmental Strategies, Vol. 2 Issue 2, pp. 263-276.

Hunt, C.B. and Auster, E.R. (1990), "Proactive environmental management: avoiding the toxic trap", MIT Sloan Management Review, Vol. 31 No. 2, pp. 7-18.

Jabbour, C.J.C. (2010), "In the eye of the storm: exploring the introduction of environmental issues in the production function in Brazilian companies", International Journal of Production Research, Vol. 48 No. 21, pp. 6315-6339.

Jabbour, C. J. C. (2015), "Environmental training and environmental management maturity of Brazilian companies with ISO14001: Empirical evidence", Journal of Cleaner Production, Vol. 96 No. 1, pp. 331-338. 
Jabbour, C.J.C. and Santos, F.C.A. (2006), "The evolution of environmental management within organizations: Toward a common taxonomy”, Environmental Quality Management, Vol. 16 No. 2, pp. 43-59.

Jabbour, C.J.C., Santos, F.C.A. and Nagano, M.S. (2010), “Contributions of HRM throughout the stages of environmental management: Methodological triangulation applied to companies in Brazil", The International Journal of Human Resource Management, Vol. 21 No. 7, pp. 1049-1089.

Judge, W. Q., Gaur, A. S. and Muller M. K. (2010), "Antecedents of shareholder activism: Evidence from a multi-country study", Corporate Governance: An International Review, Vol. 18 No. 4, pp. 258-273.

Kang, S. and Lee, K-H. (2016), "Mainstreaming Corporate Environmental Strategy in Management Research". Benchmarking: An International Journal, Vol. 23, No.3, pp. 618 650 .

Kolk, A. and Mauser, A. (2002), "The evolution of environmental management: from stage models to performance evaluation", Business Strategy and the Environment, Vol. 11 No. 1, pp. 14-31.

Landrum, N.E. (2017), "Stages of corporate sustainability: Integrating the strong sustainability worldview", Organization \& Environment, DOI: 1086026617717456.

Lee, C. Y., Lee, J. H. and Gaur, A. S. (2017), "Are large business groups conducive to industry innovation? The moderating role of technological appropriability", Asia Pacific Journal of Management, Vol. 34 No. 2, pp. 313-337.

Lee, K.H. and Schaltegger, S. (2018), Accounting for Sustainability: Asia Pacific Perspectives (Vol. 33). Springer International, New York and London.

Lucas, M.T. and Wilson, M.A. (2008), "Tracking the relationship between environmental management and financial performance in the service industry", Service Business, Vol. 2 No. 3, pp. 203-218.

Maialle, G. and Jabbour, A.B.L.D.S. (2014), "Evolutionary stages of environmental management in computer companies located in Brazil: Case studies", International Journal of Business Innovation and Research, Vol. 8 No. 3, pp. 300-315.

Merchant, H. and Gaur, A. S. (2008), “Opening the 'non-manufacturing' envelope: the next big enterprise for international business research", Management International Review, Vol. 48 No. 4, pp. 379-396.

Moreno, E.C., Lorente, J.S. and Jime Nez, J.D.B. (2004), "Environmental Strategies in Spanish Hotels: Contextual Factors and Performance", The Service Industries Journal, Vol. 24 No. 3, pp. 101-130.

Murillo-Luna, J.L., Garces-Ayerbe, C. and Rivera-Torres, P. (2011), "Barriers to the adoption of proactive environmental strategies". Journal of Cleaner Production, Vol. 19 No. 13, pp. 1417-1425.

Myers, M. D. (2003), “Qualitative Research in Information Systems”, MIS Quarterly, Vol. 21 No. 2, pp. 241-2.

Mysterud, I. (2017). Evolutionary Perspectives on Environmental Problems, Routledge, Oxon. 
Ormazabal, M. and Sarriegi, J.M. (2012), "Environmental management: Understanding its evolution through maturity states”, Environmental Quality Management, Vol. 22 No. 1, pp. 31-42.

Ormazabal, M. and Sarriegi, J.M. (2014), "Environmental management evolution: Empirical evidence from Spain and Italy", Business Strategy and the Environment, Vol. 23 No.2, pp. 73-88.

Ormazabal, M., Sarriegi, J.M., Barkemeyer, R., Viles, E. and Mcanulla, F. (2015), "Evolutionary pathways of environmental management in UK companies", Corporate Social Responsibility and Environmental Management, Vol. 22 No. 3, pp. 169-181.

Ormazabal, M., Rich, E., Sarriegi, J.M. and Viles, E. (2017), "Environmental management evolution framework: Maturity stages and causal loops”. Organization \& Environment, Vol. 30 No. 1, pp. 27-50.

Park, J.H. and Ahn, Y.G. (2012), "Strategic environmental management of Korean construction industry in the context of typology models", Journal of Cleaner Production, Vol. 23 No. 1, pp. 158-166.

Patnaik, S., Temouri Y., Tuffour, J., Tarba, S. and Singh, S.K. (2017), "Corporate Social Responsibility and Multinational Enterprise Identity: Insights from a Mining Company's attempt to localize in Ghana", Social Identities: Journal for the Study of Race, Nation and Culture, http://dx.doi.org/10.1080/13504630.2017.1386369

Primc, K. and Čater, T. (2016), "Environmental strategies in different stages of organisational evolution: theoretical foundations", Australasian Journal of Environmental Management, Vol. 23 No. 1, pp. 100-117.

Remington-Doucette, S.M., Connell, K.Y.H., Armstrong, C.M. and Musgrove, S.L. (2013) "Assessing sustainability education in a transdisciplinary undergraduate course focused on real-world problem solving: A case for disciplinary grounding". International Journal of Sustainability in Higher Education, Vol. 14 No. 4, pp. 404-433.

Responsible Travel. (2014), "What is responsible tourism?", available at: http://www.responsibletravel.com/copy/responsible-travel-and-responsible-tourism (accessed 16 January 2018).

Roome, N. (1992), "Developing environmental management strategies", Business Strategy and the Environment, Vol. 1 No. 1, pp. 11-24.

Rothenberg, S., Schenck, B. and Maxwell, J. (2005), "Lessons from benchmarking environmental performance at automobile assembly plants", Benchmarking: An International Journal, Vol. 12 No.1, pp. 5-15.

SAARC. (2015), "The South Asian Association for Regional Corporation", available at: http://www.saarc.com/the-south-asian-association-for-regional-corporation-saarc/ (accessed 16 January 2017).

Salzman, J. (2000), "Environmental protection beyond the smokestack: Addressing the impact of the service economy”, Corporate Environmental Strategy, Vol. 7 No. 1, Pages 20-37. 
Scapens, R. W. (2006), "Understanding management accounting practices: A personal journey", The British Accounting Review, Vol.38 No. 1, pp. 1-30.

Scott, W.R. (2008), Institutions and Organizations: Ideas and Interests, Sage, Thousand Oaks, CA).

Schaltegger, S., Hansen, E.G. and Ludeke-Freund, F. (2016), "Business models for sustainability", Organization \& Environment, Vol. 29 No. 1, pp. 3-10.

Schaltegger, S. Beckmann, M. and Hansen, E.G. (2013) "Transdisciplinarity in corporate sustainability: Mapping the field”, Business Strategy and the Environment, Vol. 22 No.4, pp. 219-229.

Schaltegger, S., Bennett, M. and Burritt, R. (2006), Sustainability Accounting and Reporting, Springer, Netherlands.

Schaltegger, S. and Wagner, M. (2011), "Sustainable entrepreneurship and sustainability innovation: categories and interactions", Business Strategy and the Environment, Vol. 20 No. 4, pp. 222-237.

Singh, D., Pattnaik, C., Gaur, A. S. and Ketencioglu, E. (2018), "Corporate expansion during pro-market reforms in emerging markets: The contingent value of group affiliation and unrelated diversification", Journal of Business Research, Vol. 82, pp. 220-229.

Shrivastava, P. and Hart, S. (1995), "Creating sustainable corporations", Business Strategy and the Environment, Vol. 4 No. 3, pp. 154-165.

Sonenshein, S. (2016), "How corporations overcome issue illegitimacy and issue equivocality to address social welfare: The role of the social change agent", Academy of Management Review, Vol. 41 No. 2, pp. 349-366.

Switchasia, (2010), “Greening Sri Lankan Hotels”, Switchasia Call 2009/2010, Sri Lanka.

Teixeira, A.A., Jabbour, C.J.C. \& Jabbour, A.B.L.D.S. (2012), "Relationship between green management and environmental training in companies located in Brazil: A theoretical framework and case studies", International Journal of Production Economics, Vol. 140 No. 1, pp. 318-329.

The Gazette of the Democratic Socialist Republic of Sri Lanka- Extraordinary, (2010), No. 1685/11, Department of Government Printing, Sri Lanka.

Tingey-Holyoak, L. and Burritt, R. (2012), "The Trans-disciplinary Nature of Accounting: A Pathway Towards the Sustainable Future of the Profession", in Emerging Pathways for the Next Generation of Accountants, Evans, E., Burritt, R., and Guthrie, J., (Eds.). The Institute of Chartered Accountants, Australia, pp. 93-103.

Tzschentke. N., Kirk. D. and Lynch P.A. (2004), "Reasons for Going Green in Serviced Accommodation Establishments", International Journal of Contemporary Hospitality Management, Vol.16 No. 2, pp. 116-124.

Venselaar, J. (1995), "Environmental training: industrial needs", Journal of Cleaner Production, Vol. 3 No. 2/3, pp. 9-12.

Welford, R. (2013). Corporate Environmental Management 3: Towards Sustainable Development, Routledge, New York. 
Windolph, S.E., Schaltegger, S. and Herzig, C. (2014a), “ Implementing corporate sustainability: What drives the application of sustainability management tools in Germany?", Sustainability Accounting, Management and Policy Journal, Vol. 5 No. 4, pp. 378-404.

Windolph, S.E., Harms, D. and Schaltegger, S. (2014b), "Motivations for corporate sustainability management: Contrasting survey results and implementation", Corporate Social Responsibility and Environmental Management, Vol. 21 No. 5, pp. 272-285.

World Bank. (2017), "South Asia Overview", available at: http://www.worldbank.org/en/region/sar/overview (accessed 02 December 2017).

World Travel and Tourism Council (WTTC). (2017), Economic Impact of Travel \& Tourism 2017, WTTC, London.

United Nations World Tourism Organization (UNWTO). (2017), "2017 International Year of Sustainable Tourism for Development", available at: http://www.tourism4development2017.org/about/ (accessed 10 November 2017).

United Nations, (2017). "World Economic and Social Survey 2013 Reflecting on Seventy Years of Development Policy Analysis", United Nations, New York.

Yin, R. (2009), Case Study Research: Design and Methods, Sage, Thousand Oaks, CA. 